\title{
Mortality attributable to extreme temperatures in Spain: A comparative analysis by city
}

\author{
R. Carmona a , J. Díaz ${ }^{\text {a,* }}$, I.J. Mirón ${ }^{\text {b }}$, C. Ortiz ${ }^{\text {a }}$, M.Y. Luna ${ }^{\text {c }}$, C. Linares ${ }^{\text {a }}$ \\ a National School of Public Health, Carlos III Institute of Health, Avda. Monforte de Lemos, 5, 28029 Madrid, Spain \\ ${ }^{\mathrm{b}}$ Torrijos Public Health District, Castile-La Mancha Regional Health E' Social Affairs Authority (Consejería de Sanidad y Asuntos Sociales de Castilla-La Mancha), Torrijos, Toledo, Spain \\ c State Meteorological Agency, (AEMET), Madrid, Spain
}

\section{A R T I C L E I N F O}

\section{Article history:}

Received 25 January 2016

Received in revised form 10 February 2016

Accepted 12 February 2016

Available online 21 February 2016

\section{Keywords:}

Extreme temperatures

Mortality

Prevention plans

Cost-benefit

\begin{abstract}
A B S T R A C T
Background: The Low Temperature Days (LTD) have attracted far less attention than that of High Temperature Days (HTD), though its impact on mortality is at least comparable. This lower degree of attention may perhaps be due to the fact that its influence on mortality is less pronounced and longer-term, and that there are other concomitant infectious winters factors. In a climate-change scenario, the studies undertaken to date report differing results. The aim of this study was to analyse mortality attributable to both thermal extremes in Spain's 52 provinces across the period 2000-2009, and estimate the related economic cost to show the benefit or "profitability" of implementing prevention plans against LTD.

Methods: Previous studies enabled us: to obtain the maximum daily temperature above which HTD occurred and the minimum daily temperature below which LTD occurred in the 52 provincial capitals analysed across the same study period; and to calculate the relative and attributable risks (\%) associated with daily mortality in each capital. These measures of association were then used to make different calculations to obtain the daily mean mortality attributable to both thermal extremes. To this end, we obtained a summary of the number of degrees whereby the temperature exceeded (excess ${ }^{\circ} \mathrm{C}$ ) or fell short (deficit ${ }^{\circ} \mathrm{C}$ ) of the threshold temperature for each capital, and calculated the respective number of extreme temperatures days. The economic estimates rated the prevention plans as being $68 \%$ effective.

Results: Over the period considered, the number of HTD (4373) was higher than the number of LTD (3006) for Spain as a whole. Notwithstanding this, in every provincial capital the mean daily mortality attributable to heat was lower ( 3 deaths/day) than that attributable to cold (3.48 deaths/day). In terms of the economic impact of the activation of prevention plans against LTD, these could be assumed to avoid 2.37 deaths on each LTD, which translated as a saving of $€ 0.29 \mathrm{M}$. Similarly, in the case of heat, 2.04 deaths could be assumed to be avoided each day on which the prevention plan against HTD was activated, amounting to a saving of $€ 0.25 \mathrm{M}$. While the economic cost of cold-related mortality across the ten-year period 2000-2009 was €871.7M, that attributable to heat could be put at $€ 1093.2 \mathrm{M}$.

Conclusion: The effect of extreme temperatures on daily mortality was similar across the study period for Spain overall. The lower number of days with LTD meant, however, that daily cold-related mortality was higher than daily heat-related mortality, thereby making prevention plans against LTD more "profitable" prevention plans against HTD in terms of avoidable mortality.
\end{abstract}

(c) 2016 Elsevier Ltd. All rights reserved.

\section{Introduction}

While the increase in winter mortality associated with low temperatures has been studied for a number of decades (Mackenbach et al., 1992; Kunst et al., 1993; Alberdi et al., 1998) and has more recently been associated with extremely low temperatures or cold waves (Montero et al., 2010; Díaz et al., 2005; Donaldson et al., 2001; The Eurowinter Group, 1997), it is nevertheless a phenomenon that has attracted far less attention than has the analysis of heat waves, though

\footnotetext{
* Corresponding author.

E-mail address: j.diaz@isciii.es (J. Díaz).
}

its impact on mortality is at least comparable (Linares et al., 2014), with some studies undertaken in the UK and Australia even indicating that cold-related deaths are of an order of magnitude greater than those related to heat (Vardoulakis et al., 2014). This lower degree of attention may perhaps be due to the fact that its influence on mortality is less pronounced and longer-term (Alberdi et al., 1998), and that there are other concomitant infectious winter factors (Healy, 2003), though these would not wholly account for high winter respiratory-cause mortality (Ebi and Mills, 2013). Furthermore, although the leading cause of winter mortality is respiratory, a relationship has also been found between low temperatures and morbidity-mortality due to circulatory causes (Chau et al., 2014; Xie et al., 2013; Davídkovová et al., 2014). However, the 
main reason for mortality due to low temperatures being less analysed than that due to heat - and even less so where specific causes are concerned - may perhaps be because there has never been a public health phenomenon as impressive and memorable as the heat wave that struck Europe in 2003 (García-Herrera et al., 2010). In a climate-change scenario, studies undertaken to date report differing results: whereas some indicate that the rise in temperatures attributed to climate change (IPCC, 2013) will reduce cold-related mortality (Vardoulakis et al., 2014; Kodra et al., 2011), others indicate just the opposite, namely, that global warming will not cause winter mortality to decrease (Staddon et al., 2014), and yet others indicate that there will be a shift in the balance of deaths between winter and summer (Ebi and Mills, 2013), with deaths in summer increasing and those in winter decreasing.

A recent study (Gasparrini et al., 2015a) undertaken in 348 cities across 13 countries estimated that the effect of cold was 50 times greater than that of heat and, more specifically, in the case of Spain the effect of cold was 5 times greater than that of heat. Despite this, there are very few countries which have prevention plans specifically for cold waves. Moreover, a higher mortality attributable to low temperatures has been observed in regions with milder climates, where home heating facilities and physiological adaptation to low temperatures are both different to those of other areas with more extreme climates, thus making cold wave prevention plans even more necessary in such regions. Residents in warm regions have less physical, social, and behavioural adaptation to low temperatures (Lin et al., 2013), and the effects of cold are thus more significant in warm regions (Langford and Bentham, 1995; Wang et al., 2012) or areas with moderate winter climates (Conlon et al., 2011).

Accordingly, this study sought to conduct a comparative study into mortality attributable to extreme temperatures in 52 Spanish provinces across the period 2000-2009, and draw up an estimate of the economic cost associated with high and low temperatures, with aim of showing the benefit of implementing prevention plans to combat low temperatures.

\section{Material and methods}

\subsection{Setting}

Spain is the second largest country in Western Europe $\left(504,030 \mathrm{~km}^{2}\right)$, with a total population of $46,507,760$ (INE, 2014). Mainland Spain is bordered to the south and east by the Mediterranean Sea, to the north by France and the Bay of Biscay, and to the north-west and west by the Atlantic Ocean and Portugal. Spanish territory also includes the Balearic Islands in the Mediterranean, the Canary Islands in the Atlantic Ocean off the African coast, and two autonomous enclaves in North Africa, namely, the cities of Ceuta and Melilla. The country is divided into 17 Autonomous Regions (Comunidades Autónomas), which are in turn subdivided into one to nine provinces, each with its own respective provincial capital. Due to Spain's geographical situation and conditions, the climate is extremely diverse and can be roughly classified into the following five main zones: a Mediterranean climate extending along the southern and eastern coasts up to the Pyrenees; a semi-arid Mediterranean climate in the south-east; a continental Mediterranean climate in the inland areas of mainland Spain; an oceanic climate in the northwest and along the coastal strip bordering the Bay of Biscay; and a subtropical climate in the Canary Islands (Prieto et al., 2004).

\subsection{Data}

As the health variable, we used data on daily mortality due to natural causes (International Classification of Diseases 10th Revision (ICD-10): A00-R99), in each of Spain's 52 provincial capitals and in towns and cities of over 10,000 inhabitants, across the period 1 January 2000-31 December 2009 . The daily mortality data were obtained from microfiches containing death data broken down by cause of death and supplied under a data-loan agreement by the National Statistics Institute to the Carlos III Institute of Health (Ministry of Economic Affairs \& Competitiveness/Ministerio de Economía y Competitividad), for the purpose of undertaking a "Study of influenza-related mortality in Spain". As this study was ecological in design, it was exempt from approval by a research ethics panel.

The maximum and minimum daily temperature data in degrees Celsius for this period corresponded to the records kept by the respective meteorological observatories in the various provincial capitals, and were furnished by the State Meteorological Agency (Agencia Estatal de Meteorología/AEMET), except in the case of Palencia for which there were no records for the period. The meteorological observatories were located at sites established by the State Meteorological Agency (www. aemet.es).

\subsection{Statistical analysis}

The above data analysis was performed in the various stages described below.

2.3.1. Calculation of threshold temperatures that define High/Low Temperature Days and quantification of the effect on daily mortality per province

To estimate the effect of extreme temperatures on daily mortality in the 52 provincial capitals analysed, we used previous studies (Díaz et al., 2015a; Carmona et al., 2016), conducted for the same study period (2000-2009), as described below:

- Effect of heat (Díaz et al., 2015b): this study determined the maximum daily temperature that registered the closest association with heat-related mortality. For each Spanish province, we calculated this temperature or the threshold temperature that defined High Temperature Days (Tthreshold $\mathrm{heat}_{\text {). }}$. A High Temperature Days (HTD) was defined as any day on which the threshold temperature was exceeded.

- Effect of cold (Carmona et al., 2016): analogously, in this earlier study we determined the minimum daily temperature that registered the closest association with cold-related mortality. For each Spanish province, we calculated the minimum daily temperature or Low Temperature Days (LTD) threshold temperature ( Tthreshold $_{\text {cold }}$ ), below which mortality attributable to low temperatures began to increase. A LTD was defined as any day on which the minimum temperature fell below the threshold temperature.

As measures of epidemiological association, in both studies we calculated the relative risk (RR) and attributable risk (AR), expressed as percentages, associated with daily mortality in each province. These RRs were calculated: in the case of HTD, for every increase of $1{ }^{\circ} \mathrm{C}$ above the Tthreshold ${ }_{\text {heat }}$, thereby obtaining the RRs associated with heat (RRheat); and in the case of LTD, for each degree that the minimum daily temperature fell below the Tthreshold ${ }_{\text {cold }}$, thereby obtaining the RRs associated with cold (RRcold).

\subsubsection{Calculation of the number of daily deaths attributed to extreme tem- peratures for each province}

We first calculated the number of degrees whereby the temperature exceeded (excess ${ }^{\circ} \mathrm{C}$ ) or fell short $\left(\right.$ deficit $^{\circ} \mathrm{C}$ ) of the threshold temperature for each province by means of the following expression:

Excess $^{\circ} \mathrm{C}$ in HTD $=\sum \mathrm{T}_{\max }-$ Tthreshold $_{\text {heat }}$
Deficit $^{\circ} \mathrm{C}$ in LTD $=\sum$ Tthreshold $_{\text {cold }}-\mathrm{T}_{\text {min }}$.

$\sum$ extends to all days on which the maximum daily temperature exceeded the threshold temperature in the case of HTD, and to all days on which the minimum daily temperature fell below the threshold temperature, in the case of LTD. 
On ascertaining the percentage increase in mortality for each ${ }^{\circ} \mathrm{C}$ via the AR, the total percentage mortality for the overall excess ${ }^{\circ} \mathrm{C}$ across the period 2000-2009 would be: percentage attributable to HTD = AR $\times$ excess ${ }^{\circ} \mathrm{C}$.

Accordingly, to go from percentages to daily mortality, it suffices for the mean mortality in any given province during HTD to be taken into account as follows:

- Mortality attributable to heat $=$ (percentage mortality attributable to HTD $\times$ mean mortality) / 100 .

- Daily mortality attributable to heat = mortality attributable to HTD / number of days with high temperatures.

Likewise, in the case of cold, once the percentage increase in mortality for each ${ }^{\circ} \mathrm{C}$ is ascertained (via the AR), the total percentage mortality for the overall deficit ${ }^{\circ} \mathrm{C}$ across the period 2000-2009 would be: percentage mortality attributable to LTD $=\mathrm{AR} \times$ deficit ${ }^{\circ} \mathrm{C}$.

Here again, to go from percentages to daily mortality, it suffices for the mean mortality in any given province during LTD to be taken into account as follows:

- Mortality attributable to cold = (percentage mortality attributable to LTD $\times$ mean mortality) / 100 .

- Daily mortality attributable to cold = mortality attributable to LTD / number of days with low temperatures.

\subsection{Economic estimate}

To draw up an economic estimate of the benefit to be derived from implementing prevention plans against HTD and LTD, the effectiveness of the prevention plans was assumed to be similar for heat and cold, namely $68 \%$ (Fouillet et al., 2008). We assumed 1.1 years per avoided death and monetised at $€ 0.11 \mathrm{M}$ per life-year with no senior discount (de Ayala and Spadaro, 2014). This approach is a departure from previous studies (Ebi et al., 2004), which have valued lives saved by using the value per statistical life.

\section{Results}

Table 1 shows the descriptive statistics relating to: mean daily mortality per province for LTD and HTD; and maximum and minimum daily temperatures.

Table 2 shows the excess ${ }^{\circ} \mathrm{C}$ or deficit ${ }^{\circ} \mathrm{C}$ in HTD and LTD respectively, the number of HTD and LTD, and the number of heat- and cold-related deaths per provincial capital, calculated as indicated under Material and methods.

As can be seen for Spain as a whole, although the number of HTD (4373) was higher than the number of LTD (3006) across the study period, daily heat-related mortality per provincial capital was nevertheless lower ( 3 deaths/day) than that related to cold (3.48 deaths/day).

During the study period, mean mortality per LTD, according to the data in Table 2, was 3.48 deaths/day, which amounts to a total mortality of 10,460 persons. In the case of heat, mean daily mortality attributable to heat was 3 deaths/day, which amounts to a total mortality of 13,119 persons.

In terms of the economic impact of implementing cold prevention plans, if one assumes an effectiveness of $68 \%$, then 2.37 deaths would be avoided on each LTD, amounting to a saving of $€ 0.29 \mathrm{M}$. In the case of heat, 2.04 deaths would be avoided each day on which the heat prevention plan was activated, amounting to a saving of $€ 0.25 \mathrm{M}$.

Since our study covered the total number of LTD and HTD, the economic cost of cold-related mortality across the ten-year period from 2000 to 2009 would be $€ 871.7 \mathrm{M}$, while that of heat-related mortality would be €1093.2M.
Table 1

Descriptive statistics of mortality due to natural causes, maximum and minimum temperatures $\left({ }^{\circ} \mathrm{C}\right.$ ) in days with extreme temperatures by city in Spain $2000-2009$ period.

\begin{tabular}{|c|c|c|c|c|c|c|c|c|}
\hline \multirow[t]{3}{*}{ City } & \multicolumn{4}{|c|}{ High Temperature Days } & \multicolumn{4}{|c|}{ Low Temperature Days } \\
\hline & \multicolumn{2}{|c|}{$\begin{array}{l}\text { Natural } \\
\text { mortality }\end{array}$} & \multicolumn{2}{|c|}{$\begin{array}{l}\text { Maximum } \\
\text { temperature }\end{array}$} & \multicolumn{2}{|c|}{$\begin{array}{l}\text { Natural } \\
\text { mortality }\end{array}$} & \multicolumn{2}{|c|}{$\begin{array}{l}\text { Minimum } \\
\text { temperature }\end{array}$} \\
\hline & Mean & SD & Mean & SD & Mean & SD & Mean & SD \\
\hline A Coruña & 31 & 6 & 28.0 & 1.9 & 35 & 6 & 2.8 & 0.8 \\
\hline Albacete & 8 & 3 & 37.4 & 1.0 & 10 & 4 & -6.2 & 2.4 \\
\hline Alicante & 34 & 7 & 33.4 & 1.2 & & & & \\
\hline Almería & 11 & 3 & 37.4 & 1.0 & 14 & 5 & 4.7 & 1.2 \\
\hline Ávila & 5 & 2 & 33.4 & 1.1 & 6 & 2 & -11.7 & 0.8 \\
\hline Badajoz & 17 & 5 & 39.7 & 1.3 & 22 & 6 & -1.8 & 1.4 \\
\hline Barcelona & 130 & 28 & 33.5 & 1.2 & 138 & 15 & -1.1 & 0.9 \\
\hline Bilbao & 27 & 6 & 33.2 & 2.4 & 32 & 6 & -3.2 & 0.9 \\
\hline Burgos & 10 & 4 & 35.4 & 1.1 & & & & \\
\hline Cáceres & 11 & 5 & 39.4 & 1.0 & 12 & 5 & -3.0 & 0.8 \\
\hline Cádiz & 24 & 7 & 33.6 & 1.3 & 29 & 7 & 4.5 & 1.3 \\
\hline Castellón & 12 & 4 & 33.5 & 1.5 & 16 & 5 & 0.8 & 0.9 \\
\hline \multicolumn{9}{|l|}{ Ceuta } \\
\hline Ciudad Real & 14 & 4 & 39.3 & 0.8 & 17 & 6 & -5.5 & 1.2 \\
\hline Córdoba & 18 & 6 & 41.4 & 1.1 & 26 & 7 & -3.4 & 1.5 \\
\hline Cuenca & 5 & 2 & 35.3 & 0.9 & 6 & 2 & -6.0 & 1.7 \\
\hline Girona & 16 & 5 & 37.5 & 1.3 & & & & \\
\hline Granada & 20 & 5 & 39.2 & 0.9 & 28 & 6 & -5.5 & 1.7 \\
\hline Guadalajara & 5 & 3 & 39.0 & 0.7 & 6 & 2 & -7.8 & 1.5 \\
\hline Huelva & 11 & 4 & 38.0 & 1.6 & 15 & 4 & 0.5 & 1.2 \\
\hline Huesca & 6 & 2 & 35.8 & 1.2 & 7 & 2 & -7.6 & 1.2 \\
\hline Jaén & 15 & 4 & 37.4 & 1.0 & 18 & 5 & -1.7 & 1.9 \\
\hline Las Palmas & 18 & 5 & 34.9 & 2.3 & & & & \\
\hline León & 15 & 4 & 33.2 & 0.9 & 17 & 5 & -5.9 & 1.8 \\
\hline Lleida & 10 & 3 & 37.4 & 0.9 & 13 & 4 & -4.3 & 1.7 \\
\hline Logroño & 7 & 2 & 37.4 & 1.1 & 8 & 3 & -2.3 & 1.9 \\
\hline Lugo & 13 & 4 & 35.7 & 1.4 & 15 & 5 & -7.3 & 1.1 \\
\hline Madrid & 106 & 15 & 35.5 & 1.1 & 126 & 17 & -3.4 & 1.2 \\
\hline Málaga & 31 & 5 & 41.0 & 0.7 & 36 & 8 & 2.8 & 0.9 \\
\hline \multicolumn{9}{|l|}{ Melilla } \\
\hline Murcia & 26 & 6 & 35.8 & 1.7 & 38 & 1 & 1.9 & 1.2 \\
\hline Ourense & 11 & 4 & 37.7 & 1.4 & 15 & 4 & -3.6 & 1.5 \\
\hline Oviedo & 37 & 7 & 31.9 & 1.5 & 38 & 7 & -1.2 & 1.0 \\
\hline \multicolumn{9}{|l|}{ Palencia } \\
\hline Pamplona & 14 & 5 & 37.4 & 1.0 & 14 & 4 & -7.4 & 1.3 \\
\hline P.Mallorca & 22 & 4 & 37.4 & 1.1 & 24 & 5 & -1.2 & 0.9 \\
\hline Pontevedra & 21 & 6 & 32.5 & 1.9 & 26 & 7 & 0.6 & 1.0 \\
\hline Salamanca & 10 & 3 & 35.3 & 1.0 & 12 & 3 & -6.1 & 1.7 \\
\hline Santander & 16 & 4 & 33.7 & 1.4 & 17 & 5 & 0.1 & 1.5 \\
\hline S.C. $\cdot$ Tenerife & 18 & 6 & 34.0 & 2.1 & & & & \\
\hline Segovia & 4 & 2 & 35.2 & 0.9 & 5 & 2 & -7.8 & 1.7 \\
\hline Sevilla & 40 & 12 & 41.3 & 1.1 & 50 & 10 & 0.8 & 1.1 \\
\hline Soria & 3 & 1 & 35.0 & 0.7 & 3 & 2 & -8.3 & 1.9 \\
\hline San Sebastián & 16 & 4 & 32.5 & 1.9 & & & & \\
\hline Tarragona & 17 & 5 & 37.2 & 0.9 & 19 & 5 & -1.1 & 0.7 \\
\hline Teruel & 5 & 2 & 36.8 & 0.6 & 4 & 2 & -10.6 & 2.6 \\
\hline Toledo & 14 & 4 & 39.2 & 0.9 & 18 & 7 & -7.5 & 1.3 \\
\hline Valencia & 57 & 8 & 36.3 & 1.6 & 73 & 12 & 1.0 & 1.1 \\
\hline Valladolid & 13 & 4 & 37.0 & 0.7 & 14 & 4 & -5.9 & 1.6 \\
\hline Vitoria & 6 & 2 & 35.5 & 1.1 & & & & \\
\hline Zamora & 7 & 3 & 36.8 & 0.8 & 7 & 3 & -7.5 & 1.2 \\
\hline Zaragoza & 24 & 6 & 37.6 & 1.1 & 28 & 6 & -4.0 & 1.5 \\
\hline
\end{tabular}

Fig. 1 shows the number of deaths attributable to heat across the period 2000-2009 for each provincial capital. These total deaths are the result of multiplying the figures shown in Table 2, namely: HTD $\times$ deaths/ High Temperature Days. Fig. 2 shows the number of deaths attributable to cold calculated in the same way.

\section{Discussion}

Natural-cause mortality associated with LTD for Spain as a whole, with an AR of $11.5 \%$ (95\% CI: 9.1\%-13.8\%) was similar to that detected for HTD, AR 9.9\% (95\% CI: 9.1\%-10.7\%). This finding is not in contradiction with Gasparrini's study (Gasparrini et al., 2015a), undertaken in 13 countries, which reported that the effect of cold was 50 times greater than that of heat, with a mortality attributable to cold of $7.29 \%$ (95\% CI: 
Table 2

Attributable mortality to HTD/LTD by city in Spain 2000-2009 period. HTD: High Temperature Days; LTD: Low Temperature Days.

\begin{tabular}{|c|c|c|c|c|c|c|}
\hline City & ${ }^{\circ} \mathrm{C}$ excess in $\mathrm{HTD}^{\mathrm{a}}$ & Number of $\mathrm{HTD}^{\mathrm{b}}$ & Deaths/HTD ${ }^{\mathrm{c}}$ & ${ }^{\circ} \mathrm{C}$ deficit in $\mathrm{LTD}^{\mathrm{a}}$ & Number of LTD $^{\mathrm{b}}$ & Deaths/LTD ${ }^{\mathrm{c}}$ \\
\hline A Coruña & 227.5 & 111 & 4 & 76.2 & 65 & 4 \\
\hline Albacete & 173.5 & 125 & 0.4 & 255.9 & 118 & 0.4 \\
\hline Alicante & 269.5 & 186 & 3 & 0 & 0 & 0 \\
\hline Almería & 54.6 & 39 & 2 & 74.2 & 57 & 3 \\
\hline Ávila & 175.1 & 122 & 1 & 15.5 & 9 & 2 \\
\hline Badajoz & 252.6 & 147 & 3 & 280.7 & 160 & 4 \\
\hline Barcelona & 74.3 & 49 & 25 & 34.7 & 31 & 11 \\
\hline Bilbao & 457.8 & 141 & 5 & 23.9 & 20 & 5 \\
\hline Burgos & 130 & 92 & 2 & 0 & 0 & 0 \\
\hline Cáceres & 98 & 71 & 3 & 37.2 & 36 & 1 \\
\hline Cádiz & 139.7 & 89 & 3 & 95.9 & 64 & 5 \\
\hline Castellón & 229.9 & 153 & 1 & 33.8 & 29 & 5 \\
\hline Ceuta & 0 & 0 & 0 & 0 & 0 & 0 \\
\hline Ciudad Real & 110 & 88 & 2 & 45.1 & 31 & 7 \\
\hline Córdoba & 173.2 & 125 & 3 & 35.4 & 25 & 7 \\
\hline Cuenca & 218 & 171 & 0.5 & 195.8 & 100 & 0.4 \\
\hline Girona & 62.8 & 41 & 2 & 0 & 0 & 0 \\
\hline Granada & 86.1 & 70 & 3 & 29.3 & 19 & 9 \\
\hline Guadalajara & 36.5 & 36 & 1 & 143.8 & 78 & 1 \\
\hline Huelva & 258.2 & 129 & 2 & 100.3 & 68 & 4 \\
\hline Huesca & 328.7 & 187 & 1 & 26 & 16 & 1 \\
\hline Jaén & 207.4 & 144 & 2 & 54.5 & 32 & 2 \\
\hline Las Palmas & 88.3 & 30 & 5 & 0 & 0 & 0 \\
\hline León & 98 & 79 & 2 & 324.2 & 174 & 1 \\
\hline Lleida & 159.2 & 110 & 2 & 389.3 & 170 & 2 \\
\hline Logroño & 100 & 72 & 1 & 633.1 & 276 & 1 \\
\hline Lugo & 48.8 & 29 & 3 & 33.7 & 26 & 3 \\
\hline Madrid & 321.1 & 211 & 11 & 42.8 & 30 & 19 \\
\hline Málaga & 8.3 & 8 & 4 & 60.4 & 50 & 11 \\
\hline Melilla & 0 & 0 & 0 & 0 & 0 & 0 \\
\hline Murcia & 63.8 & 36 & 1 & 8.4 & 4 & 17 \\
\hline Ourense & 180.7 & 104 & 1 & 184.5 & 112 & 2 \\
\hline Oviedo & 77.9 & 40 & 8 & 110.5 & 92 & 4 \\
\hline Palencia & 0 & 0 & 0 & 0 & 0 & 0 \\
\hline Pamplona & 88.8 & 65 & 3 & 32.6 & 24 & 1 \\
\hline P.Mallorca & 62.7 & 45 & 4 & 114.6 & 95 & 4 \\
\hline Pontevedra & 355.3 & 142 & 4 & 118.6 & 85 & 5 \\
\hline Salamanca & 164.5 & 125 & 1 & 488.7 & 231 & 1 \\
\hline Santander & 30.8 & 18 & 2 & 266.7 & 143 & 2 \\
\hline S.C. $\cdot$ Tenerife & 133.4 & 66 & 3 & 0 & 0 & 0 \\
\hline Segovia & 103.9 & 85 & 0.5 & 81.2 & 44 & 1 \\
\hline Sevilla & 98.4 & 74 & 8 & 72 & 62 & 10 \\
\hline Soria & 50.6 & 53 & 0 & 216.2 & 93 & 0.3 \\
\hline San Sebastián & 143.2 & 57 & 3 & 0 & 0 & 0 \\
\hline Tarragona & 93.1 & 75 & 3 & 47.3 & 44 & 1 \\
\hline Teruel & 28 & 36 & 0 & 185.2 & 71 & 0 \\
\hline Toledo & 135.1 & 113 & 2 & 10.6 & 7 & 5 \\
\hline Valencia & 118.8 & 52 & 9 & 19 & 19 & 15 \\
\hline Valladolid & 57 & 57 & 2 & 146.9 & 76 & 1 \\
\hline Vitoria & 83.5 & 54 & 1 & 0 & 0 & 0 \\
\hline Zamora & 44.8 & 53 & 1 & 46.8 & 31 & 1 \\
\hline Zaragoza & 274.8 & 168 & 3 & 180.2 & 89 & 1 \\
\hline Spain & 134.2 & 4373 & 3.00 & 103.3 & 3006 & 3.48 \\
\hline
\end{tabular}

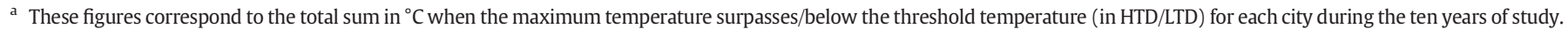
The value for Spain is the mean for all the cities values.

b These figures correspond to the total sum in days that the maximum temperature surpasses/below the threshold temperature (in HTD/LTD) for each city during the ten years of study. The value for Spain is the sum for all the cities values.

c These figures correspond to the mean mortality for each city attributable to HTD/LTD. The value for Spain is the mean for all cities values.

$7.02 \%-7.49 \%$ ) versus $0.42 \%$ for mortality attributable to heat $(95 \% \mathrm{CI}$ : $0.39 \%-0.44 \%$ ), since in that study the impact was due to mortality attributable to heat and cold, and not to HTD and LTD as analysed by us. Specifically, in the case of Spain, a minimum mortality temperature was established at the 78th percentile of the mean daily temperature series, and on the basis of this the effects of cold and heat (temperatures respectively below and above this percentile) were then calculated, which accounts for the fact that the results yielded by Gasparrini's study for Spain would be appreciably lower in the effects of heat $1.1 \%$ (95\% CI: $1.0 \%-1.2 \%$ ) and cold 5.5\% (95\% CI: 4.8\%-6.1\%). In our study, the threshold temperatures were based on epidemiological criteria which took into account a far broader range of the underlying factors that influence the different mortality patterns and vary from one region to another, such as socio-economic conditions, ability to adapt to local climate type (Guo et al., 2014), lifestyle, and population structure.

The results obtained in this study are consistent with those of another comparative heat and cold study conducted in The Netherlands (Huynen et al., 2001), which reported that cold waves had an attributable mortality ( $12.8 \%$ or 46.6 deaths/day) slightly higher than that of heat waves ( $12.1 \%$ or 39.8 deaths/day). Similarly, a study undertaken at the US Centres for Disease Control and Prevention (CDC) showed that $63 \%$ temperature-related deaths were attributable to cold exposure, while only $31 \%$ were attributable to heat exposure (Berko et al., 2014).

The results in Table 2 clearly indicate that, for Spain as a whole, attributable mortality associated with heat (1312 deaths/year, this mean 


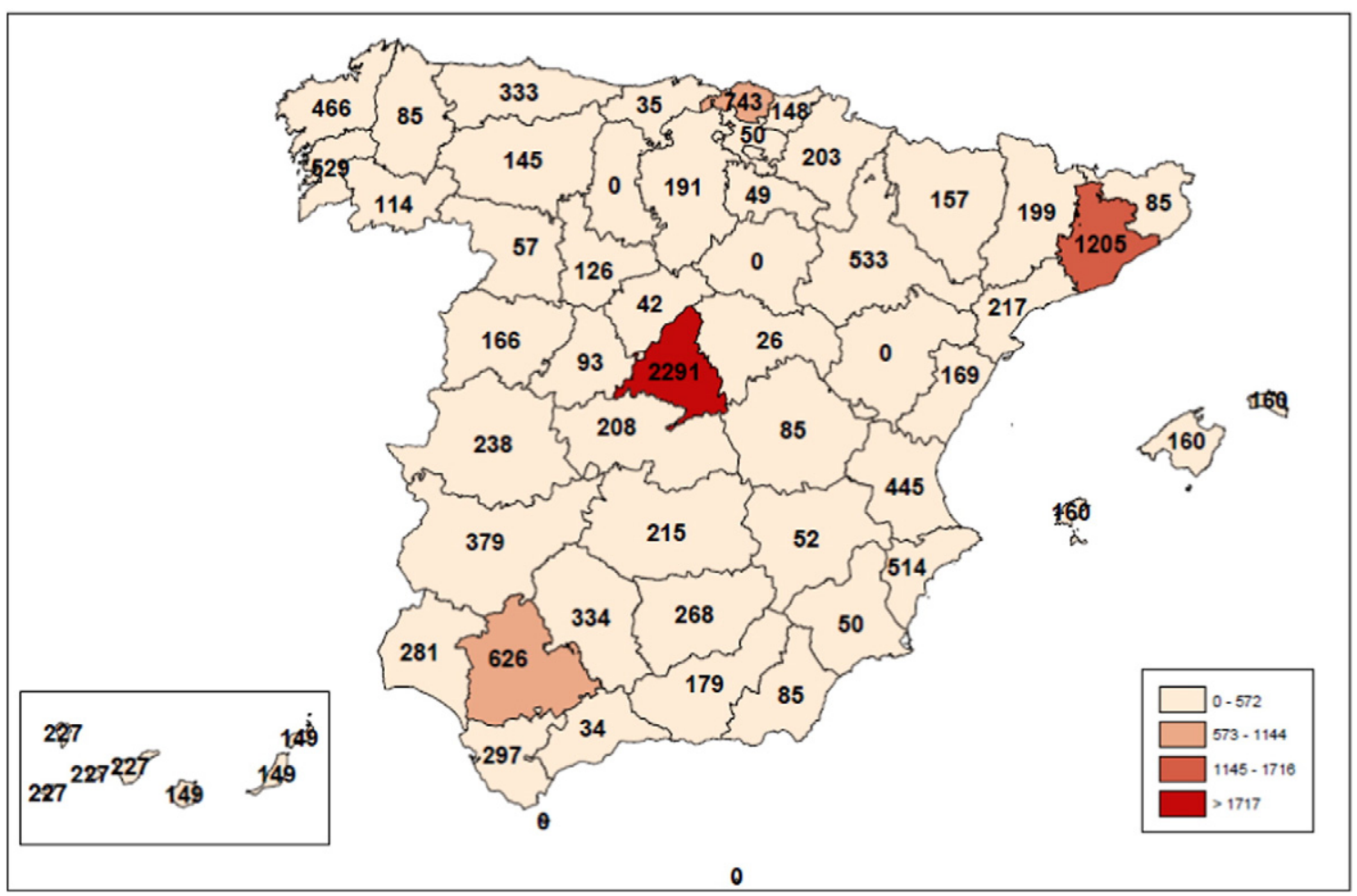

Fig. 1. Number of deaths attributable to High Temperature Days across the period 2000-2009 for each provincial capital.

that 13,119 deaths divided by 10 years corresponding to the study period), was slightly higher than that associated with cold (1046 deaths/ year, this mean 10,460 deaths divided by 10 years corresponding to the study period). Nevertheless, it is the lower number of LTD (301 days/year) versus HTD (437 days/year) registered nationwide which accounts for the fact that the daily impact on attributable mortality was greater for cold than for heat.

Although these annual mortality figures attributable to heat and cold are in themselves justification enough for the need to implement prevention plans against both thermal extremes, their economic

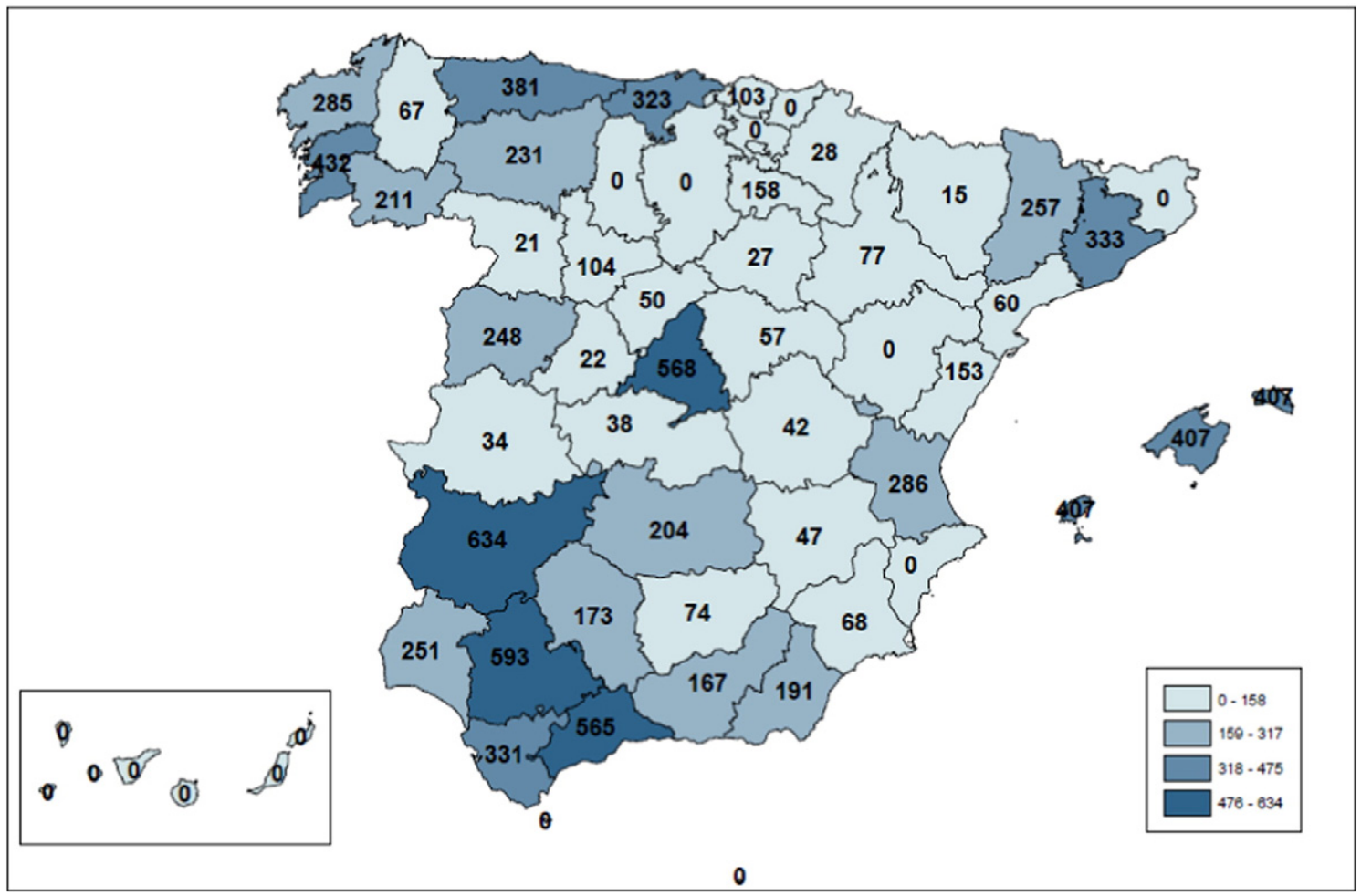

Fig. 2. Number of deaths attributable to Low Temperature Days across the period 2000-2009 for each provincial capital. 
quantification, showing a slightly greater benefit associated with cold ( $€ 0.29 \mathrm{M} /$ day in LTD) than with heat ( $€ 0.25 \mathrm{M} /$ day in HTD), would also support this hypothesis. On the other hand, it also has to be said that the effects of cold on mortality tend to be longer-term than those of heat (Alberdi et al., 1998; Linares et al., 2015), and so this economic advantage might perhaps be cancelled out. Most of heat and cold related deaths generally are in elderly people whose economic value is less. In this study the authors have not used a senior discount economic value; the study has been performed over general population with all the age groups included.

A study conducted in Philadelphia (Ebi et al., 2004) indicated that the gross benefits of the Philadelphia heat wave warning system could be in the order of US\$468 million (117 lives saved $\times$ US\$4 million), in that activation of the heat wave plan over a 3-year period reduced daily mortality by 2.6 lives on average. It should be pointed out that this figure is very similar to that obtained by us (2.04).

In Fig. 1, which depicts heat-attributable mortality across the study period, attention should be drawn to the high mortality registered in Madrid and Barcelona in comparison with the remaining Spanish provinces. This is due to the fact that both Barcelona and Madrid register a higher daily mortality (Table 1 ) and, by extension, a higher attributable mortality, and in addition that Madrid is the city which registered the highest number of HTD (211 in the study period), a direct consequence of the low percentile (82nd percentile) calculated by Díaz et al., 2015a, corresponding to the mortality threshold or "trigger" temperature for this city (maximum daily temperature of $34^{\circ} \mathrm{C}$ ). In the case of Barcelona, however, despite daily mortality in the HTD period being higher (Table 1), the high percentile (96th percentile) calculated by Díaz et al., 2015a, to which the HTD mortality trigger temperature corresponds (maximum daily temperature of $32^{\circ} \mathrm{C}$ ), means that the number of HTD ( 49 days) was actually lower than that of Madrid. This lower number of HTD is offset by the fact that Barcelona's AR (12.4\%) is higher than that of Madrid (6.7\%) (Díaz et al., 2015a) but is nevertheless insufficient to offset the 211 HTD experienced by Madrid versus the 49 experienced by Barcelona.

In the case of mortality attributable to LTD (Fig. 2), note should be taken of the high mortality registered by cities with relatively mild climates, such as Malaga, Seville and Badajoz. As can be seen in Table 2, the number of LTD was not excessively high in any of the three, nor did these cities' daily mortality correspond to the maximum values for Spain during this period (see Table 1). It was the high ARs for cold that accounted for the attributable mortality being high, especially in Seville and Malaga (Carmona et al., 2016). This finding, namely, that places with mild climates register a higher mortality attributable to cold than do those with colder climates, is in line with results observed elsewhere in Europe, and would appear to be linked to home heating facilities (The Eurowinter Group, 1997; Thomson et al., 2001).

Furthermore, there are studies which indicate that the effect of heat on mortality is declining (Mirón et al., 2015; Gasparrini et al., 2015b) whereas that of cold is, at the very least, remaining constant (Mirón et al., 2012). More specifically, in a study conducted for the city of Madrid (Díaz et al., 2015a), which analysed the effect of cold and heat in the period 1986-1997 by age group and then compared it to that for the period 2001-2009, the effect of heat was observed to have decreased in practically all age groups, whilst that of cold had increased, particularly in the over-65 segment. This is especially relevant, bearing in mind the ageing of the population which is being experienced by most developed countries, and by Spain in particular (38.7\% of the population in 2064 vs. 18.2\% at present) (INE, 2014).

With respect to the limitations of this study and any possible resulting biases, the following should be mentioned: firstly, an ecological study such as ours, does not permit inferences to be made at the level of individuals, for fear of the ecological fallacy arising as a result of the use of pooled data. With reference to the quality and consistency of the data analysed, there might possibly have been poor classification of the cause of mortality. Another possible limitation lies in the representativeness of temperatures that were recorded in provincial capitals in all cases, a point discussed by some earlier papers (Mirón et al., 2006; Roldán et al., 2011). With regard to the non-use of other environmental variables of interest, such as air pressure and relative humidity, these were not included in the analysis owing to their negligible relevance in the temperature-mortality relationship (Barnett et al., 2010; Montero et al., 2012). Insofar as particulate air pollution is concerned, the lack of quality data at a national level rendered their use inadvisable, owing to the risk of introducing instability into the complete series (Linares et al., 2014). In addition, the use of low daily numbers of deaths in some cities, generally leads to higher confidence intervals and less accurate findings.

Among the causes attributed to a decrease in the effects of heat on mortality, some are inherent to socio-demographic and health-care conditions (Mirón et al., 2015) and would be equally applicable to the case of cold, but others are directly related to activation of prevention plans (Abrahamson et al., 2008), the design of cities to minimise the effects of heat (Georgescu et al., 2014), the expected increase in population resilience as a result of physiological acclimatisation to warmer climates (Gosling et al., 2009; Konkel, 2014), or even the better provision of infrastructures that are exclusively applicable to heat and contribute to what has come to be known as the "heat culture" (Konkel, 2014) that has developed over the last decade. None of this exists in the case of cold. Furthermore, the idea of global warming and rising temperatures (IPCC, 2013), albeit not associated with the disappearance of cold waves (Kodra et al., 2011), would also seem to oppose the generation of the type of "cold culture" that would be likely to result in a decrease in cold-related mortality, as occurred in the case of heat.

\section{Acknowledgements}

This study was supported by grants FIS ENPY 1001/13 \& SEPY 1037/ 14 from Spain's Health Research Fund.

\section{References}

Abrahamson, V., Wolf, J., Lorenzoni, I., et al., 2008. Perceptions of heatwave risks to health: interview-based study of older people in London and Norwich, UK. Journal of Public Health $31,119-126$

Alberdi, J.C., Díaz, J., Montero, J.C., Mirón, I.J., 1998. Daily mortality in Madrid community 1986-1992: relationship with meteorological variables. Eur. J. Epidemiol. 14, 571-578.

Barnett, A.G., Tong, S., Clements, A.C.A., 2010. What measure of temperature is the best predictor of mortality? Environ. Res. 110, 604-611.

Berko, J., Ingram, D.D., Saha, S., Parker, J.D., 2014. Deaths attributed to heat, cold, and other weather events in the United States, 2006-2010. National Health Statistics Reports, No. 76. National Center for Health Statistics, U.S. Centers for Disease Control and Prevention, Hyattsville, MD (30 July, Available at: http://www.cdc.gov/nchs/data/nhsr/ nhsr076.pdf [accessed 30 September 2015]).

Carmona, R., Díaz, J., Ortíz, C., León, I., Mirón, I.J., Linares, C., 2016. Geographical variation in relative risks associated with cold waves: the need for a cold wave prevention plan. Environ. Int. 88, 103-111.

Chau, P.H., Wong, M., Woo, J., 2014. Ischemic heart disease hospitalization among older people in a Subtropical City-Hong Kong: does winter have a greater impact than summer? Int. J. Environ. Res. Pub. Health 11, 3845-3858.

Conlon, K.C., Rajkovich, N.B., White-Newsome, J.L., Larsen, L., O'Neill, M.S., 2011 Jul. Preventing cold-related morbidity and mortality in a changing climate. Maturitas 69 (3), 197-202.

Davídkovová, H., Plavcova, E., Cyncl, J., Kysely, J., 2014. Impacts of hot and cold spells differ for acute and chronic ischaemic heart diseases. BMC Public Health 14, 480.

de Ayala A, Spadaro JV. Economic costs of health impacts. Report prepared for the European Commission under the Public health impacts in URban environments of Greenhouse gas Emissions reduction strategies (PURGE) Project, 7th Framework Programme under GA No. 265325. http://purge.lshtm.ac.uk/. 2014.

Díaz, J., García, R., López, C., Linares, C., Aurelio, A., Prieto, L., 2005. Mortality impact of extreme winter temperatures. Int. J. Biometeorol. 49, 179-183.

Díaz, J., Carmona, R., Mirón, I.J., Ortiz, C., Linares, C., 2015a. Comparison of the effects of extreme temperatures on daily mortality in Madrid (Spain), by age group: the need for a cold wave prevention plan. Environ. Res. 143, 186-191.

Díaz, J., Carmona, R., Mirón, I.J., Ortiz, C., León, I., Linares, C., 2015b. Geographical variation in relative risks associated with heat: update of Spain's Heat Wave Prevention Plan. Environ. Int. 85, 273-283.

Donaldson, G.C., Rintamäki, H., Näyhä, S., 2001. Outdoor clothing: its relationship to geography, climate, behavior and cold-related mortality in Europe. Int. J. Biometeorol. 45, 45-51. 
Ebi, K.L., Mills, D., 2013. Winter mortality in a warming climate: a reassessment. Wiley Interdiscip. Rev. Clim. Chang. 4, 203-212.

Ebi, K.L., Teisberg, T.J., Kalkstein, L.S., Robinson, L., Weiher, R.F., 2004. Heat watch/warning systems save lives: estimated costs and benefits for Philadelphia 1995-98. Bull. Am. Meteorol. Soc. 85, 1067-1073.

Fouillet, A., Rey, G., Wagner, V., et al., 2008. Has the impact of heat waves on mortality changed in France since the European heat wave of summer 2003? A study of the 2006 heat wave. Int. J. Epidemiol. 37, 309-317.

García-Herrera, R., Díaz, J., Trigo, R.M., Luterbacher, J., Fischer, E.M., 2010. A review of the European summer heat wave of 2003. Crit. Rev. Environ. Sci. Technol. 40, 267-306.

Gasparrini, A., Guo, Y., Hashizume, M., Lavigne, E., Zanabettia, A., et al., 2015a. Mortality risk attributable to high and low ambient temperature: a multicountry observational study. Lancet http://dx.doi.org/10.106/s0140-6736(14)62114-0.

Gasparrini, A., Guo, Y., Hashizume, M., Kinney, P., Petkova, E.P., Lavigne, E., et al., 2015b. Temporal variation in heat-mortality associations: a multicountry study. Environ. Health Perspect. http://dx.doi.org/10.1289/ehp.1409070.

Georgescu, M., Morefield, P.E., Bierwagen, B.G., Weaver, C.P., 2014. Urban adaptation can roll back warming of emerging megapolitan regions. Proc. Natl. Acad. Sci. 111 (8), 2909-2914.

Gosling, S.N., McGregor, G.R., Lowe, J.A., 2009. Climate change and heat-related mortality in six cities. Part 2: climate model evaluation and projected impacts from changes in the mean and variability of temperature with climate change. Int. J. Biometeorol. 53, 31-51.

Guo, Y., Gasparrini, A., Armstrong, B., Li, S., Tawatsupa, B., Tobias, A., et al., 2014 Nov. Global variation in the effects of ambient temperature on mortality: a systematic evaluation. Epidemiology 25 (6), 781-789.

Healy, J.D., 2003. Excess winter mortality in Europe: a cross country analysis identifying key risk factors. J. Epidemiol. Community Health 57, 784-789.

Huynen, M.M., Martens, P., Schram, D., Weijenberg, M.P., Kunst, A.E., 2001. The impact of heat waves and cold spells on mortality rates in the Dutch population. Environ. Health Perspect. 109 (5), 463-470 (May).

INE 2014. Proyecciones de Población de población (2014-2064) residente en España a 1 de enero. http://www.ine.es/prensa/np870.pdf.

IPCC 2013. Climate change. The physical science basis. Working Group I contribution to the Fifth Assessment Report of the Intergovernmental Panel on Climate Change. 2013.

Kodra, E., Steinhaeuser, K., Ganguly, A.R., 2011. Persisting cold extremes under 21stcentury warming scenarios. Geophys. Res. Lett. 38, L08705.

Konkel, L., 2014. Learning to take the heat: declines in U.S. heat-related mortality. Environ. Health Perspect. http://dx.doi.org/10.1289/ehp.122-A220.

Kunst, E.A., Looman, C.W.N., Mackenbach, J.P., 1993. Outdoor air temperature and mortality in the Netherlands: a time-series analysis. Am. J. Epidemiol. 137, 331-341.

Langford, I.H., Bentham, G., 1995. The potential effects of climate change on winter mortality in England and Wales. Int. J. Biometeorol. 38, 141-147.

Lin, Y.K., Wang, Y.C., Lin, P.L., Li, M.H., Ho, T.J., 2013. Relationships between coldtemperature indices and all causes and cardiopulmonary morbidity and mortality in a subtropical island. Sci. Total Environ. 461-462, 627-635 (Sep 1).

Linares C, Carmona R, Díaz, J. Análisis del impacto a corto plazo de los extremos térmicos y de otros factores ambientales sobre la mortalidad diaria en la ciudad de Madrid en el periodo 2001-2009. Reports I and II Prepared for the European Commission Under the BASE (Bottom-UP Climate Adaptation Strategies Towards a Sustainable Europe) Project, 7th Research Framework Programme Under GA. 2014. No. 308, 337.

Linares, C., Diaz, J., Tobias, A., Carmona, R., Mirón, I.J., 2015. Impact of heat and cold waves on circulatory-cause and respiratory-cause mortality in Spain: 1975-2008. Stoch. Env. Res. Risk A. 29, 2037-2046.

Mackenbach, J.P., Kunts, A.E., Looman, C.W.N., 1992. Seasonal variation in mortality in the Netherlands. J. Epidemiol. Community Health 46, 261-265.

Mirón, I.J., Montero, J.C., Criado, J.J., Gutiérrez, G., Paredes, D., Mayoral, S., Linares, C., 2006 Tratamiento y estudio de series de temperatura para su aplicación en salud pública. El caso de Castilla-La Mancha. Rev. Esp. Salud Publica 80, 113-124.

Mirón, I.J., Montero, J.C., Criado-Álvarez, J.J., Linares, C., Díaz, J., 2012. Intense cold and mortality in Castile-La Mancha (Spain): study of mortality trigger thresholds from 1975 to 2003. Int. J. Biometeorol. 56, 145-152.

Mirón, I.J., Linares, C., Montero, J.C., Criado, J.J., Díaz, J., 2015. Changes in cause-specific mortality during heat waves in Castile-La Mancha: Spain, 1975-2008. Int. J. Biometeorol. 59, 1213-1222.

Montero, J.C., Mirón, I.J., Criado-Álvarez, J.J., Linares, C., Díaz, J., 2010. Mortality from cold waves in Castile-La Mancha. Sci. Total Environ. 408, 5768-5774.

Montero, J.C., Miron, I.J., Criado-Alvarez, J.J., Linares, C., Diaz, J., 2012. Influence of local factors in the relationship between mortality and heat waves: Castile-La Mancha (1975-2003). Sci. Total Environ. 414, 73-80 (Jan 1).

Prieto, L., García-Herrera, R., Díaz, J., Hernández, E., Tesoa, T., 2004. Minimum extreme temperatures over peninsular Spain. Glob. Planet. Chang. 44, 59-71.

Roldán, E., Gómez, M., Pino, M.R., Esteban, M., Díaz, J., 2011. Determinación de zonas isoclimáticas y selección de estaciones meteorológicas representativas en Aragón como base para la estimación del impacto del cambio climático sobre la posible relación entre la mortalidad y temperatura. Rev. Esp. Salud Publica 85, 603-610.

Staddon, P.L., Montgomery, H.E., Depledge, M.H., 2014. Climate warming will not decrease winter mortality. Nat. Clim. Chang. http://dx.doi.org/10.1038/NCLIMATE2121.

The Eurowinter Group, 1997. Cold exposure and winter mortality from ischaemic heart disease, cerebrovascular disease, respiratory disease, and all causes in warm and cold regions of Europe. Lancet 349, 1341-1346.

Thomson, H., Petticrew, M., Morrison, D., 2001. Health effects of housing improvement: systematic review of intervention studies. BMJ 323 (7306), 187-190 (Jul 28).

Vardoulakis, S., Dear, K., Hajat, S., Heaviside, C., Eggen, B., 2014. Comparative assessment of the effects of climate change on heat-and cold-related mortality in the United Kingdom and Australia. Environ. Health Perspect. http://dx.doi.org/10.1289/ehp. 1307524.

Wang, Y.C., Lin, Y.K., Chuang, C.Y., Li, M.H., Chou, C.H., Liao, C.H., et al., 2012. Associating emergency room visits with first and prolonged extreme temperature event in Taiwan: a population-based cohort study. Sci. Total Environ. 416, 97-104.

Xie, H.Y, Yao, Z.B, Zhang Y.H. Xu, YJ. Xu, XJ, Liu, T, et al, 2013. Short term effects of the 2008 cold spell on mortality in three subtropical cities in Guangdong Province, China. Environ. Health Perspect. 121, 210-216. 